\title{
Suid-Afrikaanse kapelaansvroue en die Grensoorlog (1966-1989): 'n Gevallestudie van denominale pastorale versorging
}

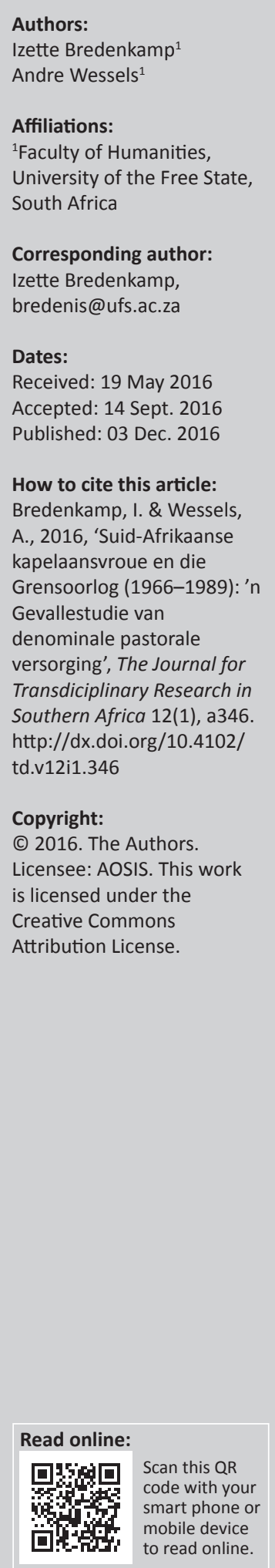

South African chaplains' spouses and the Border War (1966-1989): A case study of denominational pastoral care. Pastoral care of soldiers during times of war and armed conflict has been part and parcel of the Christian religion since the Council of Ratisbon officially authorised chaplains for armies in 742. However, studies in South Africa revealed that government institutions and especially the Dutch-Afrikaans denominations did not wholeheartedly adhere to this tradition during the two world wars of the twentieth century. The task of pastoral care to those affected by the war circumstances was left to civilian organisations and women. Socio-political changes invalidated this accussation during the Border War (1966-1989). This article gives a historical perspective on the pastoral care endeavours of the spouses of military chaplains as a case study of denominational support to those affected by armed conflict. Women's experiences during war circumstances have long been neglected in academic circles. During times of war, they are often the victims of human rights' abuses, but they also become beacons of hope and consolation, as is illustrated in this article. This exposition contributes to a historical understanding of the way women experience war and the support they provide during times of armed conflict. It also illustrates the value of women during times of war trauma, and provides a different perspective on the military context, which is usually mostly defined in masculine terms.

In die Christelike tradisie is die pastorale versorging van soldate tydens oorlogsomstandighede en gewapende konflik 'n gegewe sedert die Konsilie van Ratisbon in 742, toe gelas is dat kapelane die leërs moet vergesel. Studie in Suid-Afrika het egter 'n versuim van owerheidsweë, en veral van die kant van die Hollands-Afrikaanse kerke in Suid-Afrika aangetoon om oorloggeaffekteerdes en oorlogbetrokkenes tydens die twee wêreldoorloë van die twintigste eeu pastoraal te versorg. Hierdie taak is in SuidAfrika aan burgerlike organisasies en vroue oorgelaat. Tydens die Grensoorlog (1966-1989) het die prentjie egter verander. Hierdie artikel wil 'n historiese perspektief verskaf op die uitreikevan dieeggenotesvan militêrekapelane, as'ngevallestudievan geloofsgemeenskappe se pastorale versorging van diegene wie se lewens deur gewapende konflik geraak word. Vroue se ervarings gedurende tye van oorlog en gewapende konflik is vir'n geruime tyd in akademiese geskiedskrywing genegeer. Vroue is dikwels gedurende oorlogsomstandighede slagoffers van menseregtevergrype, maar hulle kan ook as bakens van hoop, vertroosting en heropbou na vore tree soos hierdie artikel probeer aantoon. Hierdeur word 'n bydrae tot 'n historiese begrip van die belewenis van vroue tydens oorlogsomstandighede gemaak, asook die wyse waarop vroue ondersteuningsnetwerke kan skep in gemeenskappe wat deur gewapende konflik geraak word. Dit illustreer verder die waarde van vroue ten tye van oorlogstrauma, en dit gee 'n ander perspektief op die militêre konteks wat gewoonlik in manlike terme gedefinieer word.

\section{Introduction}

This article forms part of a project on the history of military chaplains in the cluster: Social transformation in diverse societies: Focus area: Identities and histories at the University of the Free State. Military chaplaincy in South Africa was initiated during the First World War (1914-1918), but it only received official recognition as an integral part of the structures of the former South African Defence Force (SADF) in 1973. This implies that the South African Military Chaplaincy Service (SACHS) did not receive the support it was entitled to during the two world wars of the twentieth century. The situation was aggravated by the fact that, because of sociopolitical reasons, the Afrikaans-Dutch denominations left the task of pastoral care of those 
affected by the war circumstances to civil organisations and the endeavours of women. However, changes in the sociopolitical situation of South Africa in the post-war period invalidated the accusation of neglect during the Border War (1966-1989) - South Africa's longest war and for many the only contemporary experience of war circumstances. One of the neglected aspects of military chaplaincy is the role and influence of the spouses of military chaplains. This article reflects on the pastoral outreaches of the spouses of South African military chaplains during the Border War, as a case study of denominational pastoral care during times of armed conflict. Studies revealed that women experience armed conflict differently from their male counterparts. In modern warfare, women are often active combatants, but traditionally they experienced war circumstances as part of the civilian population. For quite some time academic writing neglected the experiences of women during times of armed conflict. It was only during the 1970s that the feminist movement placed women and war circumstances central to the academic debate and on the agendas of many international organisations. Although women are often the victims of human rights' abuses during times of armed conflict, they can also become beacons of hope and consolation, as is illustrated in this article.

\section{Method and data}

The focal area of this article is history. The historical narrative was used to make an incision in the socio-cultural design of South African femininity, focusing on the spouses of South African military chaplains who, as the wives of clergy through their endeavours to address the trauma of the Border War, became a case study of the pastoral care of denominations during times of armed conflict. Data were collected from interviews with the spouses of chaplains, news reports and reports from the official military publications, Paratus and In Hoc Signo, and documentation from the private collection of Ms Ria van Rensburg, wife of the late Maj. Gen. (Rev.) C.P. Naudé, Chaplain-General for the period 1983-1990. In the wake of the formation of the new South African National Defence Force (SANDF) in 1994, other documents regarding the spouses of chaplains seem to have been discarded during clean up processes. At present, the Military Archives in Pretoria does not possess any unpublished documents regarding the spouses of South African military chaplains.

\section{Discussion}

The focal point of this article involves the pastoral care administered by spouses of South African military chaplains to the military community of the SADF during the time of the Border War (1966-1989). This is used as a case study of denominational outreaches in the South African community during times of armed conflict and war circumstances. The spouses of South African military chaplains were involved in many spiritual matters regarding the military community especially four of these were specifically directed towards the alleviation of war trauma during the timeframe of the Border War. Although the war commenced in 1966, the endeavours of chaplains' spouses gained momentum only in the late 1970s after the SACHS was acknowledged as an integral part of the SADF, and the timeframe of this discussion is therefore mostly from 1975 onwards. The endeavours of chaplains' spouses include pastoral care towards Permanent Force soldiers' families during long periods of absence because of border duty; Christmas parcels were sent to women and children of Permanent Force members who resided in the operational area in Northern Namibia for longer periods than the usual three months of border duty; Melita served as a guest house for the family members of wounded and injured soldiers in 1 Military Hospital at Voortrekkerhoogte (at present Thaba Tshwane), Pretoria; and they ran the coffee bar project, which was embedded in the need for leisure facilities in the operational area.

Although the civilian population also experienced the upheaval in family relations caused by the call to arms to serve in the operational area in the north of Namibia, it was the families of Permanent Force members who experienced the brunt of these orders for periods of up to six months. The duties and liabilities at home increased tremendously for spouses of Permanent Force soldiers and it was coupled with uncertainty and anxiety for the safety of their husbands. In the light of this trauma, the spouses of chaplains embarked on a project aiming to alleviate the trauma through Bible studies, visits, invitations to functions, telephone calls, flowers and spiritual reading material. On the return of Permanent Force soldiers, they supported families in reintegrating again, and accepting the father figure as the head of the household. They also published the booklet, Net maar ' $n$ woord/Just a word, which consisted of short, spiritually encouraging pieces, written by chaplains' spouses.

Since 1978 chaplains' spouses sent Christmas parcels to the wives and children of Permanent Force soldiers stationed in the operational area of northern Namibia. Because of the costs of this project, it was decided to send only Christmas cards from 1986 to 1989. Since 1984 Christmas cards were also sent to family members of chaplains connected to the South African diplomatic missions. The project was under the supervision of the Chaplains' Wives Committee for the first two years, but since 1980 a rotation system with regard to the military districts and divisions was used.

One of the most challenging projects of the spouses of chaplains was the renovation and enlargement of the Red Cross hut at the then called Voortrekkerhoogte. It was furnished to serve as an overnight facility for family members of wounded or injured soldiers in 1 Military Hospital. Melita, as it was called, not only provided lodging for those traumatised by the injuries of their loved ones but also provided support and pastoral care. Small wonder, it was called, 'a deed of love'. Chaplains' wives not only carried the costs of the project but also made sure that monthly needs with regard to refreshments, cleaning agents and flowers were provided. 
Shortly after the transfer of the protection duty of the northern border of Namibia from the South African Police to the SADF, chaplains noticed the lack of recreational facilities in the operational area. To this end, the coffee bar project was initiated by the Chaplains' Wives Committee. It provided a recreational space different from the canteens where soldiers could relax in a homely atmosphere. Music, reading material, games and biscuits were provided on a regular basis. Over time the coffee bars became spiritual spaces for those in the operational area. In 1981 there were four coffee bars in the operational area and by 1985 the number had risen to 48 .

\section{Conclusion}

The spouses of South African military chaplains were able to enrich the ministry of chaplains and to expand the boundaries of pastoral care during the war circumstances of the Border War, not only in the military context but also with regard to the wider South African community. In doing so they not only became an example of denominational pastoral care during times of war and armed conflict, but also illustrated the worth of women in addressing trauma in society. This article not only provides a different perspective on the military context, which is usually defined in masculine terms, but the history of the ministry of churches and chaplains during the Border War will be incomplete without taking into account the endeavours of the spouses of military chaplains.

\section{Inleiding en agtergrond}

Hierdie artikel vorm deel van 'n projek rondom die geskiedenis van die Suid-Afrikaanse militêre kapelaansbediening. Dit het as gevolg van die behoeftes van oorlogbetrokkenes tydens die Eerste Wêreldoorlog (1914-1918) beslag gekry, maar is eers in 1973 as ' $n$ volwaardige ondersteuningsdiens van die destydse Suid-Afrikaanse Weermag (SAW) erken (Bredenkamp \& Wessels 2012:244-245). In die Christelike tradisie is die pastorale versorging van soldate tydens oorlogsomstandighede en gewapende konflik sedert die Konsilie van Ratisbon in 742 'n gegewe (Potgieter 1971:68). In 742 is gelas dat kapelane die leërs moes vergesel. Traagheid vanaf Suid-Afrikaanse owerheidsweë om die kapelaansbediening as 'n volwaardige ondersteuningsdiens van die SAW te erken, het daartoe gelei dat die SuidAfrikaanse Kapelaansdiens (SAKD) in die tydperk voor 1973 nie die ondersteuning tydens oorlogsomstandighede ontvang het waarop dit geregtig was nie. Hierdie aspek is deur J.M. van Tonder (2014:123, 130-140) in sy studie oor die pastorale rol van Hollands-Afrikaanse kerke gedurende die Tweede Wêreldoorlog (1939-1945) onderstreep, toe hy tot die gevolgtrekking gekom het dat hierdie kerke nie hulle versorgingsverantwoordelikheid teenoor oorloggeaffekteerdes en -betrokkenes nagekom het nie. Die aanklag van Van Tonder teen die Hollands-Afrikaanse kerke en die traagheid van owerheidsweë impliseer nie 'n doelbewuste versuim om hulle pastorale verpligtinge na te kom nie, maar verwys na ' $n$ fenomeen waarvan die historiese wortels in die Suid-Afrikaanse sosiaal-politieke bedeling lê.
Trouens, dieselfde situasie het ook tydens die Eerste Wêreldoorlog voorgekom en het in 'n tekort aan Afrikaanssprekende kapelane tydens beide oorloë (vgl. Bredenkamp \& Wessels 2014b:71, 76) gemanifesteer.

Oorlogsomstandighede is in wese abnormaal en oorloggeaffekteerdes en -betrokkenes word aan trauma en emosionele spanning in verskillende grade van intensiteit blootgestel (OASSSA 1988:13; Van Tonder 2014:120-122). Pastorale versorging veronderstel dus nie alleen besondere geestelike versorging nie, maar ook dat die maatskaplike nood wat in hierdie abnormale omstandighede ontstaan, hanteer moet word. Van Tonder (2014:122) haal Heitink aan wanneer hy die kerk se pastorale verantwoordelikheid tydens oorlogsomstandighede omskryf as die aanknoop van 'n verhouding met iemand in nood wat tot gevolg het dat so 'n persoon ondersteuning en troos op sy moeilike weg ervaar. Hierdie ondersteuning lê nie alleen in 'n geestelike boodskap van bemoediging nie, maar ook in ' $n$ planmatige versorging en voorsiening in die nood van die dag. Ook Hendriks (1999:189) koppel pastorale versorging aan dienslewering: 'Bij het pastorale [...] staat het belang van de bezochte centraal en gaat het om dienstverlening'. Geloofsgemeenskappe se versorgingsverantwoordelikheid vloei dus uit hulle barmhartigheidsdiens en in die Christelike geloof is dit in die liefdesgebod van die Bybel gegrondves (vgl. Du Toit 1955:9-10). Van Tonder (2014:120) gaan van die standpunt uit dat pastorale bedienaars deur die voorbeeld van Jesus Christus geïnspireer word: 'Met versorging word bedoel barmhartigheid as Christelike liefdadigheid en hulpbetoon aan almal wat in nood en ellende is'. Heyns (1977) beskryf dit soos volg:

Die diens van die kerk word bepaal deur die diens van Christus [...] Dit sal met ander woorde nie ' $n$ diens wees bloot om medemenslikheidsoorweginge nie, maar moet voortspruit uit 'n eerlike deelname aan en persoonlike betrokkenheid by die nood en lyding van mense om Christus ontwil [...] Deur hierdie daadgetuienis bewys die kerk dat Jesus gesterwe en opgestaan het [...]. (p. 122)

Dit is opmerklik dat ' $n$ verandering in die sosiaal-politieke bedeling gedurende die na-oorlogse jare daartoe gelei het dat die aanklag van versuim teen die Hollands-Afrikaanse kerke nie ook tydens die Grensoorlog (1966-1989) ${ }^{1}$ geldig was nie - Suid-Afrika se langste oorlog was ook vir baie Suid-Afrikaners die enigste eietydse ervaring van oorlogsomstandighede. Trouens, die meerderheid kapelane tydens die Grensoorlog het uit die Hollands-Afrikaanse denominasies gekom (vgl. Bredenkamp \& Wessels 2012:249). Studies soos dié van S.G. van Niekerk (2002:253-316) en die mondelinge getuienis van kapelane (vgl. Wessels \& Bredenkamp 2009b:339-360) dui daarop dat kapelane die pastorale versorging van soldate tydens die Grensoorlog as hulle hoogste roeping gesien het. In hierdie taak het hulle die heelhartige ondersteuning van hulle eggenotes 
en die Kapelaansvrouebediening ervaar (Van Rensburg 2012). ${ }^{2}$ Ook van owerheidsweë het die Grensoorlog bygedra om erkenning aan die SAKD as 'n volwaardige ondersteuningsdiens in die SAW te gee (vgl. Wessels \& Bredenkamp 2009a:319-320).

Omdat vroue oorlogsomstandighede tradisioneel as deel van ' $n$ burgerlike samelewing ervaar het, is min van hulle belewenisse tydens konfliktye gedokumenteer. Dit kan aan twee faktore toegeskryf word: die oorlogsveld is tot diep in die twintigste eeu as ' $n$ manlike terrein geïnterpreteer, en die sosiale wetenskappe het vir baie jare 'n neutrale navorsingsbenadering in die studie van oorlog en konflik gevolg. Dit het inderwaarheid die manlike siening vir alle groepe geldend gemaak (Skjelsbæk \& Smith 2001:1-2). Eers gedurende die sewentigerjare van die vorige eeu het die feministiese beweging die fenomeen van vroue en oorlogsomstandighede sentraal in akademiese debatvoering en op die agenda van talle internasionale konferensies geplaas. ${ }^{3}$ Klem is veral op vroue se ervarings as slagoffers van menseregtevergrype geplaas, maar navorsing het ook getoon dat hulle dikwels as bakens van hoop en heropbou na vore tree (Lindsey 2001:14-15; Skjelsbæk \& Smith 2001:vii-viii, 1, 5; Treacher et al. 2008:1). In sy studie wys Van Tonder (2014:139-140) daarop dat vroue en buitekerklike instansies tot 'n groot mate die pastorale taak van die HollandsAfrikaanse kerke tydens die Tweede Wêreldoorlog oorgeneem het en ' $n$ belangrike rol in die bemoediging en versorging van oorloggeaffekteerdes en -betrokkenes gespeel het. Annette Strauss (2006:371) het ook bevind dat talle vroue vrywillig 'n bydrae tot die ondersteuning en versorging van soldate tydens die Grensoorlog gelewer het deur die sogenaamde 'Dankie tannie'-projekte. Hierdie artikel wil vanuit 'n historiese perspektief en deur middel van die narratiewe metode 'n snit in die sosiaal-kulturele opset van SuidAfrikaanse vroue maak. Die klem gaan op kapelaansvroue val wat as predikantsvroue ${ }^{4}$ deur hulle uitreike tydens

\footnotetext{
2.In die feministiese teorie word dienslewering deur vroue binne die werkskring van hulle eggenote dikwels binne die 'domestic'- of 'motherism'-raamwerk geplaas. Jacklyn Cock argumenteer dat eggenotes van lede van die SAW, onder druk van die Weermagdamesvereniging se verwagtings van lojaliteit en ondersteuning aan Weermagdamesvereniging se verwagtings van lojaliteit en ondersteuning aan hulle mans, tot ' $n$ groot mate hulle eie identiteit prysgegee het om by hulle
soldaat-eggenoot se wêreld in te skakel. Die SAW as instelling het hierdie definisies soldaat-eggenoot se wêreld in te skakel. Die SAW as instelling het hierdie definisies van gender-onderdanigheid versterk. Cock bevind ook dat vroue hierdeur nie alleen bygedra het om die Suid-Afrikaanse samelewing te militariseer nie, maar ook om die ideologie van gender-rolle te versterk (sien Cock 1991:51, 120-124, 234; Cock \& Nathan 1989:56-58). Hoewel hierdie aspek wel'n rol by dienslewering deur vroue gedurende die sestiger- tot tagtigerjare van die vorige eeu gespeel het - ook buite die SAW - kan dit egter nie as die enigste of selfs belangrikste motivering tot dienslewering by vroue gesien word nie. In die onderhawige geval sou godsdienstige oorwegings as Christene waarskynlik'n ewe belangrike dryfveer gewees het. Dat hierdie debatvoering oor gender-rolle gekompliseerd is, spreek duidelik uit die feit dat Kamila Klingorová en Tomáš Havlič (2015:2-3) godsdiens duidelik uit die feit dat Kamila Klingorová en Tomaśs Havlić (2015
}

3.Vrouehistoriografie het as gevolg van die feministiese beweging, internasionaal reeds gedurende die sestigerjare van die vorige eeu beslag gekry en gedurende die sewentigerjare in ' $n$ studieveld met ' $n$ eie momentum ontwikkel. Gedurende die tagtigerjare het dit van die polities-radikale feministiese inslag wegbeweeg en as genderhistoriografie ' $n$ neutrale akademiese dissiplinevorm aangeneem (Blignaut 2012:12-13, 17). Ten spyte daarvan dat genderstudies by verskeie Suid-Afrikaanse universiteite gevestig is en nie-regeringsorganisasie-werkswinkels en seminare oo die onderwerp aangebied is (Bonnin 1996:380-382), wys Belinda Bozzoli en Pete Dalius in 1990 daarop dat vrouehistoriografie in Suid-Afrika nog in sy kinderskoen is. Skrywers wat binne die raamwerk van genderhistoriografie 'n belangrike bydrae gelewer het, sluit onder meer die volgende persone in: Belinda Bozzoli, cyare Claine Robertis die publikasierl 2007 verskyn het (Ntwape 2016:1, 19, 22-24, 26, 28,41,51,60).

4.Vir ' $n$ vollediger uiiteenseting van die rol van kapelaansvroue as predikant- en offisiersvroue in die militêre milieu, sien Bredenkamp en Wessels (2014a:120-140). die Grensoorlog 'n gevallestudie geword het - 'n gevallestudie van geloofsgemeenskappe se pastorale antwoord op die eise van oorlogsomstandighede. Hieronder tel die pastorale uitreik na die alleenvrou wie se man grensdiens verrig het; die kerspakkies vir gesinne van staandemagsoldate wat op 'n meer permanente basis in die operasionele gebied gestasioneer was; Melita, wat huisvesting en ondersteuning aan die naasbestaandes van gewonde en beseerde soldate gegee het; asook die koffiekamerprojek wat sy ontstaan in die ontspanningsgeriewe van die operasionele gebied gehad het.

Daar moet gewaak word teen 'n oorvereenvoudigde prentjie van vroue as vredesgesind en as bakens van hoop en heropbou (vgl. Cohn 2013:1-2; Skjelsbæk 2001:64). Dit moet ook in gedagte gehou word dat die militêre konteks en gender tans baie meer kompleks is as gedurende 1966 tot 1989. Tog het kapelaansvroue daarin geslaag om die geestelike bediening van die SAKD gedurende die Grensoorlog te verruim, en terselfdertyd die grense van denominale pastorale diensbaarheid in die Suid-Afrikaanse gemeenskap te verskuif. Hierdeur het hulle 'n voorbeeld van geloofsgemeenskappe se pastorale versorging van oorloggeaffekteerdes en betrokkenes geword. Uiteraard kan die geskiedenis van kerke en kapelane se betrokkenheid by die Grensoorlog nooit volledig wees indien die pastorale uitreike van kapelaansvroue tydens hierdie oorlog nie ook in aanmerking geneem word nie. Daar moet ook daarop gelet word dat, hoewel die Grensoorlog vanaf 1966 tot 1989 strek, kapelaansvroue se pastorale uitreike eers gedurende die tweede helfte van die sewentiger jare momentum gekry het. Hierdie artikel fokus dus wat tydsafbakening betref, merendeels op 1975 tot 1989.

Hierdie artikel is op die mondelinge getuienis van kapelaansvroue, koerantberigte en berigte uit die amptelike militêre publikasies, Paratus en In Hoc Signo gebaseer, asook op dokumentasie wat deur me Ria van Rensburg bewaar is. sy was die eggenote van wyle genl.-maj. (ds.) C.P. Naudé, kapelaan-generaal vanaf 1983 tot 1990. Ander dokumente, onder andere vergaderingsnotules, is ongelukkig tydens opruimingsprosesse vernietig. Tans beskik die Militêre Argief, Pretoria, oor geen ander ongepubliseerde dokumente van die Kapelaansvrouediens nie.

\section{Kapelaansvroue en oorlogsomstandighede} Die alleenvrou

As gevolg van die eskalering van konflik, het die SAW die verdediging van die noordelike grens van SuidwesAfrika (SWA, tans Namibië) in 1973 by die Suid-Afrikaanse Polisie (SAP) oorgeneem. Die Grensoorlog was nie 'n konvensionele oorlog nie. Militêre optrede het enersyds uit lae intensiteitsinsypeling deur die South West Africa People's Organisation (SWAPO) en sy militêre vleuel, die People's Liberation Army of Namibia (PLAN), in die noordelike grensgebied van SWA bestaan, om met terreurdade die SuidAfrikaanse administrasie van SWA te ontwrig. Aan die ander 
kant het hakkejag- en voorkomingsoperasies deur die SAW tot invalle in die suidelike dele van Angola gelei. Baie hiervan was klandestiene operasies waarvan die publiek min of hoegenaamd niks geweet het nie. ${ }^{5}$ In wese was dit 'n oorlog van ideologieë, verstrengel in die Koue Oorlog-sentimente van Kommunisme en 'n westerse demokratiese bestel (Scholtz 2013:3-5; Steenkamp 1989:15).

Navorsing oor vroue en oorlogsomstandighede wys daarop dat biologiese verskille en die invloed van gemeenskapsrolparadigmas tot gevolg het dat mans en vroue militêre konflik uiteenlopend ervaar (Cohn 2013:22-23). Oorlogvoering het sedert die laaste dekades van die twintigste eeu radikaal verander met die toenemende deelname van vroue in aktiewe oorlogvoering (vgl. Die Transvaler 1993:12). Omdat vroue tradisioneel militêre konflik as deel van 'n burgerlike gemeenskap beleef het, was oorlogstrauma vir hulle egter dikwels aan die lotgevalle van hulle eggenote of seun(s) gekoppel. Gewapende konflik het skeiding, onsekerheid, bekommernis oor die veiligheid en die moontlike verlies van dierbares beteken. Al hierdie faktore het bepaalde aanpassings in die gesinsopset, familiebande en die gemeenskapsnetwerk meebring (Boshoff 1982:13; Cohn 2013:2; Lindsey 2001:216-217). Veral ten opsigte van die versorging van hulle families word vroue deur oorlogsomstandighede dikwels in 'n nuwe sosiale orde geforseer, waar hulle die tradisionele rol van die man as broodwinner en besluitnemer moet oorneem. Met die terugkeer van hulle eggenote moet hulle weer 'n 'normale' bestaan volg (Cohn 2013:29-32, 140; Kumar 2001:7-25, 54; Peterson 2008:15). 'n Uiterste vorm van oorlogstrauma is in woordewisselings en verhoudingspannning geleë, waar die blootstel aan konfliksituasies 'n subkultuur van gesinsgeweld kan skep (Boshoff 1982:13; Lindsey 2001:45). Marwick (1977:163) wys daarop dat trauma vir vroue tydens oorlogsomstandighede in die hand gewerk word deur 'n gebrek aan konstantes, want verandering gedurende gewapende konflik is altyd wisselend en onvoorspelbaar. Sommige veranderings kan positief as bemagtigingselemente dien (vgl. Lindsey 2001:30-31; Samuel 2001:201-202), maar die spanning wat beleef word tydens die druk om by onbekende situasies aan te pas, kan ook sy tol eis. Waar swangerskappe en klein kindertjies betrokke is, kan aanvaar word dat vroue meer kwesbaar is. Dit is daarom nie vreemd dat in gevalle van gewapende konflik, dit dikwels die vrou is wat ekstra ondersteuning nodig het nie. Vroue begryp die behoeftes van ander vroue in moeilike situasies beter en een van die bevindings van die International Committee of the Red Cross (ICRC) is dat vroue in oorlogsomstandighede hulle tot ondersteuningsgroepe of netwerke van hulle eie geslag wend vir die skep van 'n nuwe huishoudelike en sosiale ondersteuningsbasis (Kumar 2001:98; Lindsey 2001:32, 40, 145).

Een van die aspekte wat in die militêre omgewing van 1973 tot 1989 uitgestaan het, was die oproepinstruksies vir grensdiens. Hoewel gesinne in die burgerlike lewe ook

\footnotetext{
5.Vir meer besonderhede omtrent omstrede klandestiene operasies, sien onder andere Steyn en Söderlund (2014).
}

geraak is, was dit veral staandemagsoldate wat vir lang periodes met grensdiens van die huis afwesig was en wie se huwelike en gesinslewe aan hoë eise onderwerp is (Barnard 2002:6-7; RRP/G). Soms is ' $n$ hele eenheid opgeroep en het die vroue en kinders vir tussen drie en ses maande alleen agtergebly. Hierdie omstandighede het, in ooreenstemming met navorsing rondom vroue en oorlogsomstandighede, 'n ommeswaai in die daaglikse lewenspatroon en pligte van die betrokke gesinne beteken. As betreklik jong vroue van ongeveer 30 jaar het weermagvroue se verantwoordelikhede tuis en met betrekking tot die versorging en opvoeding van die kinders vermeerder. Hulle moes by nuwes situasies en onbekende rolparadigmas aanpas, terwyl onsekerheid en spanning oor die veiligheid van hulle eggenote altyd aanwesig was. Hiertoe het die internasionale sekerheidsgebruik van stilswye oor militêre operasies bygedra. Daar is dikwels gesê: 'The only thing harder than being a soldier, is loving one' (De Vos 1990:42; Meiring 2012; RRP/G; Van Rensburg 2012).

Ria van Rensburg (2012; RRP/G) vertel dat kinders ook die vertrek van hulle vaders as ontwrigtend ervaar het. Hulle was bewus van die gevare verbonde aan grensdiens en 'n kindergebed wat dikwels gehoor is, was: 'Liewe Jesus, help tog asseblief dat hulle nie in hul wagposisies aan die slaap sal raak nie.' As onderwyseres kon sy baie keer vir soldate se kinders by die skool in die bres tree omdat grensdiens ook hulle gedrag en skoolwerk beïnvloed het; prestasies en punte het gedaal en 'n mens kon die verandering in huislike omstandighede selfs aan hulle skrif agterkom. Veral seuns het dikwels op 'n jong ouderdom gepoog om die verantwoordelikhede van die vaderfiguur in en om die huis oor te neem. Me Van Rensburg verwys ook na Emily Hobhouse se oordeel dat oorlog vir vroue 'n bitter tyd is wat mank gaan aan die opwinding en glorie wat mans so aantreklik vind, en dat dit die swaarste op die kinders val (RRP/G).

In hierdie omstandighede het die Kapelaansvrouekomitee ${ }^{6}$ dit 'n projek van kapelaansvroue:

gemaak om vir die alleenvrou 'n ondersteuningsnetwerk daar te stel en om haar pastoraal deur persoonlike kontak, uitnodigings na die pastorie, en ondersteuning en bemoediging deur telefoonoproepe en tuisbesoeke by te staan, asook die neem van blomme en geestelike leesstof. Kapelaansvroue het ook 'n leidende rol gespeel om funksies te reël om die gedempte atmosfeer in 'n eenheid op te helder. Bybelstudie het 'n belangrike rol gespeel om vroue in hierdie vreemde, veeleisende omstandighede te leer om die situasie te aanvaar en die Here werklik te vertrou (De Vos 1990:42; Die kapelaansvroue SAW 1982:12-13; RRP/G). Wanneer die mans vir maande weg was, is 'n boekie oor gebeure in die eenheid saamgestel, gekopieer en as 'n nuusbrief aan die soldate in die operasionele gebied gestuur.

6. Hoewel kapelaansvroue lidmaatskap van die onderskeie weermagafdelings (Lee... Lugmag, Vloot en Geneeskundige Dienste) se damesverenigings gehad het het hulle hul tak in die Suid-Afrike Dienste) se damese het hulle hul taak in die Suid-Afrikaanse Weermag as eiesoortig gedefinieer en in 1976 die Kapelaansvrouekomitee gestig. Hierdie vereniging het uit die eggenote van die Kapelaanshoofkwartier bestaan en het tot die vroeë negentigerjare van die vorige eeu die werksaamhede van die verskillende weermagafdelings se kapelaansvroue gekoördineer en leiding geneem in uitreike deur kapelaansvroue. Vir meer inligting oor die Kapelaansvrouekomitee, sien Bredenkamp en Wessels (2015:77-101) 
Vroue is aangemoedig om foto's oral in die huis te plaas sodat veral babas en kleuters nie die vader met sy terugkeer as vreemd sou ervaar nie. (De Vos 1990:42; RRP/G; Van Rensburg 2012)

As ondersteuningsgroep het kapelaansvroue ook met die aanpassings ingetree wat gemaak moes word met die terugkeer van staandemagsoldate. Hulle het positiewe leiding geneem om die vaderfiguur weer sy regmatige plek in die huis te laat inneem. Vroue is aangemoedig om doelbewus sekere take wat hulle tydens hulle eggenote se afwesigheid verrig het, weer aan hulle mans op te dra, en om die kinders in die alledaagse gang van sake na hulle pa's te verwys (Die kapelaansvroue SAW 1982:43-45, 50-53; Van Rensburg 2012). Daarbenewens het kapelaansvroue die alleenvrou ook aangemoedig om in te skakel en by die sosiale vrouegroeperings en aksies in die eenheid betrokke te raak (Die kapelaansvroue SAW 1982:43; RRP/C:6; Van Rensburg 2012). Op hierdie wyse is onderlinge vriendskapbande gesmee wat as ondersteuningsbasis onvervangbaar was. Talle respondente het getuig dat die vroue in die eenheid soos een groot familie was. Hulle het mekaar onderling gehelp en sou byvoorbeeld motorbande help omruil en na mekaar se kinders omsien ten einde geleenthede te skep om probleme op te los. Hierdie vriendskapsbande het gegeld selfs nadat daar nie meer bande met die weermag bestaan het nie (Cornelissen 2013; Paratus 1982b:111; Van Rensburg 2012).

Die Kapelaansvrouekomitee het besef dat die alleenvrou 'n behoefte aan geestelike versorging het en daarom het hulle in 1980 'n publikasie, Net maar 'n woord/Just a word, die lig laat sien. Dit het uit kort, geestelike boodskappies bestaan wat deur kapelaansvroue geskryf is - boodskappe deur vroue vir vroue. Dit is gratis aan staandemag-, kommmandoen burgermagsoldate se eggenotes beskikbaar gestel. Omdat oproepinstruksies ook lede van die burgerlike samelewing geraak het, kon kerke buite die SAW dit teen 'n vrywillige donasie aanvra. Die komitee wat verantwoordelik was vir die saamstel van die bundel, het uit die volgende kapelaansvroue bestaan, mee A. Pretorius, D. Kemp, R. Cilliers, J. Daines en Z. Potgieter. Die eerste oplaag het uit 15000 eksemplare bestaan, terwyl die tweede druk in 1981 uit 30000 kopieë bestaan het. Die Kapelaansfonds het die koste van R16 000 gedra. Hoewel beskeie, het hierdie publikasie in die abnormale omstandighede van oorlogstoestande en die onsekerheid en bekommernis wat daarmee gepaard gegaan het, vir menige vroue baie beteken. Met die beëindiging van die Grensoorlog in 1989 was die oplaag uitgeput (Die kapelaansvroue SAW, 1982:128; KADW 1982a:6; RRP/A:3; RRP/B:22-23).

\section{Kerspakkies}

Sedert 1975 ná die eerste SAW-oorgrensoperasie in Angola wat as Operasie Savannah ${ }^{7}$ bekend geword het, het die SAKD 'n beleid gevolg dat die kerk daar moet wees waar dit die nodigste is - op die voorpunt van die gevegslinies. Sedertdien het kapelane as deel van die bemannings van 7.Vir meer besonderhede omtrent die inval in Angola, sien onder andere Spies (1989) en Scholtz (2013:7-34) infanteriegevegsvoertuie en ander militêre voertuie, dieselfde gevare as die troepe getrotseer (Van Niekerk 2002:279-280). Kapelaansvroue was gevolglik intens van die eise van grensdiens bewus. Onder leiding van me Elsa van Zyl, eggenote van die eerste kapelaan-generaal, genl.-maj. (ds.) J.A. van Zyl (1973-1983), het die Kapelaansvrouekomitee die behoefte uitgespreek om 'n grensprojek aan te pak. Daar was reeds verskeie uitreike na die soldate op die grens (vgl. Botha 1978:13; The Friend 1979:4), maar die Kapelaansvrouekomitee het gevoel dat die vroue en kinders van staandemaglede wat meer permanent in die operasionele gebied in SWA gestasioneer was, oor die hoof gesien word. Kapelaansvroue het daarom met 'n Kersaksie begin wat spesifiek op die vroue en kinders in die operasionele gebied gerig was. Op hierdie wyse wou hulle hulle dank en erkentlikheid aan hierdie families betoon vir die opofferings wat hulle in die vreemde maak, en hulle ook verseker dat hulle nie deur die mense van Suid-Afrika vergeet word nie (Die kapelaansvroue SAW 1982:127-128; KADW 1981:4-5; 1982b:7-8; RRP/A:2-3).

Hierdie projek is in 1978 die eerste keer onderneem en het daarna 'n jaarlikse instelling geword. Gedurende die eerste twee jaar het die Kapelaansvrouekomitee die verantwoordelikheid vir die versending van die Kerspakkies op hulle geneem, maar vanaf 1980 tot 1985 het die hantering van die projek tussen die verskillende kommandemente se kapelaansvroue geroteer. Die projek het elke jaar groter afmetings aangeneem en is deels deur die Kapelaansvrouefonds gefinansier. Fondse was egter beperk en daar is sterk op kapelaansvroue se kreatiwiteit gesteun. Die koste het egter in die laat-tagtigerjare so 'n omvang aangeneem dat daar besluit is om vorentoe slegs Kerskaarte te stuur. Dit was die tendens van 1986 tot 1989 (KADW 1983b:6; Paratus 1982a:75; RRP/A:2-3).

Die verantwoordelike kommandement se kapelaansvroue het self op die aard van die geskenke besluit en dit was ook hulle verantwoordelikheid om vooraf die geslag, name, ouderdomme en taalvoorkeure van die betrokke gesinne te bekom. Die pakkies is persoonlik aan elke vrou en kind gerig en geskenke is gekies om by die ouderdomme van die kinders te pas. Dit het sagte speelgoed, karretjies, popklere, storieboeke, sleutelhouers of toiletsakkies ingesluit. Die besendings is aan elke betrokke sektor se kapelaan oorhandig wat dit dan uitgedeel het (KADW 1981:5; 1982b:7-8; 1983b:7; RRP/A:2-3).

Kapelaansvroue van die Kommandement OVS het in 1980 aangebied om die projek te hanteer. Hulle het navraag gedoen hoe die projek deur die Kapelaansvrouekomitee bedryf is en daarop voortgebou. Kapelaansvroue van Kroonstad en Bethlehem het ruim donasies gestuur, maar dit was die Bloemfonteinse kapelaansvroue wat die projek prakties moes uitvoer. Hulle het met oorleg die geskenke aangekoop, toegedraai en van name voorsien. 'n Eksemplaar van die kapelaansvrouepublikasie, Net maar ' $n$ woord/Just a word, is aan elke vrou in die operasionele gebied gestuur, terwyl alle geskenke ook 'n kaartjie met 'n geestelike 
strekking ingesluit het (KADW 1981:4-5; Van Niekerk 2002:224). In 1981 is die projek deur die kapelaansvroue van die Kommandement Noord-Transvaal hanteer. Onder leiding van me Grietjie Jordaan — wie se man as kapelaan-generaal vanaf 1990 tot 1994 gedien het - is 743 pakkies na die operasionele gebied gestuur. Die kapelaansvroue het vier dae onverpoos gewerk om hierdie reuse taak af te handel, aangesien elke geestelike boodskappie met die hand geskryf is (KADW 1982b:7-8). Die daaropvolgende jaar het die Kommandament Westelike Provinsie die projek hanteer en gedurende 1984 het die Lugmag en die Suid-Afrikaanse Geneeskundige Dienste onder leiding van me Anita Wessels geestelike boeke en groetekaartjies wat met droë blomme versier was, uitgestuur. Gedurende 1984 is kerskaarte ook vir die eerste keer na die kapelaanspersoneel wat by buitelandse missies gestasioneer was, gestuur en dit het daarna ' $n$ vaste instelling geword. In 1989 is hierdie gebruik ook na diegene wat by Walvisbaai ${ }^{8}$ gestasioneer was, uitgebrei (KADW 1983b:6-7; 1985a:6; RRP/A:2-3; RRP/ D:Afd. B). Gedurende 1985 het die Kommandament SuidKaapland verantwoordelikheid vir die projek geneem. Daar is besluit om die ouerhandleiding van Arnold Mol, Ouerskap is nie kinderspeletjies nie, aan die vroue in die operasionele gebied te stuur en R4 440 is hiervoor ingesamel van kerke, vroue-aksies, besighede, leëreenhede, vriende en familie. Die kapelaansvroue het kerskaartjies gemaak om voor in elke boek te plak, maar die teleurstelling was groot toe die boeke nie betyds opgedaag het nie. 'n Kapelaanskonferensie in Pretoria het die saak beredder en die kapelane het, onder streng opdragte en voorskrifte van hulle vroue, die geskenke opgemaak en versend (KADW 1986a:7; RRP/A:3).

Die kapelaansvroue verklaar dat hulle in die kleinheid van die geskenke en kaartjies, die groot waarde van die Heilsboodskap wou vasvang (KADW 1982b:8). Die talle briewe van waardering wat van sowel die grens as die buitelandse missies ontvang is, getuig daarvan dat hierdie gebaar aan sy doel beantwoord het. Veral in die operasionele gebied het dit daartoe bygedra om die moreel tydens Kerstyd te versterk (KADW 1981:5; Van Niekerk 2002:224). Vir die kapelaansvroue self het dit 'n hegte onderlinge band van vriendskap help smee (KADW 1983b:7).

\section{Melita}

Een van die besonder uitdagende projekte wat die Kapelaansvrouekomitee aangepak het, was die opknapping, verbouing en bestuur van die Rooikruishut te Voortrekkerhoogte (vandag Thaba Tshwane) in Pretoria. Dit het sedert die Tweede Wêreldoorlog as verblyfplek vir besoekende naasbestaandes van siek en gewonde soldate in 1 Militêre Hospitaal gedien (Die kapelaansvroue SAW 1982:128; KADW 1980a:3; RRP/A:11). Reeds in 1971 het die Weermagdamesvereniging ${ }^{9}$ die hospitaalhut met bydraes

\footnotetext{
8.Die Walvisbaai-enklawe was tot Maart 1994 nog deel van Suid-Afrika, waarna die Suid-Afrikaanse regering die gebied formeel aan Namibië oorgedra het.

9.Die Suid-Afrikaanse Weermagdamesvereniging is in 1970 onder voorsitterskap van me Gertie Hiemstra, eggenote van die destydse Kommandant-generaal van die Suid-Afrikaanse Weermag, gestig. Dit het as 'n sambreelorganisasie vir die verskillende weermagafdelings (Leër, Lugmag, Vloot en Geneeskundige Dienste) se damesverenigings gedien (RRP/B:1, 8).
}

toegerus wat vanaf die verskillende weermagafdelings se damesverenigings ontvang is. Die beheer van die hospitaalhut is aanvanklik aan die Kommandement Noord-Transvaal oorhandig (KADW 1980a:3; RRP/B:9), maar die Kapelaansvrouekomitee het uiteindelik die verantwoordelikheid vir die huisvesting en geestelike versorging van inwoners van die Rooikruishut aanvaar.

In 1976 het die Kapelaansvrouekomitee onderneem om gereeld Bybels en geestelike lektuur vir besoekers aan die Rooikruishut beskikbaar te stel (RRP / A:11). 'n Kapelaansvrou wat in 1978 daar tuisgegaan het, het die depressiewe toestande onder die Kapelaansvrouekomitee se aandag gebring. Ondersoek is ingestel en na onderhandelings met verskeie SAW-instansies, is die beheer van die Rooikruishut na die Kapelaansvrouekomitee oorgeplaas. Hulle het onderneem om die Rooikruishut op te knap en het ook die finansiële verantwoordelikheid daarvoor aanvaar (KADW 1980a:3; RRP/A:11; Van Niekerk 2002:224-225). Planne vir die veranderings en aanbouings is opgestel en op 5 Mei 1980 is met die bouwerk begin. Kapelaansvroue oor die hele land het meegewerk om die verblyfoord, wat as Melita bekend sou staan, toe te rus. Die naam beteken 'toevlugsoord' en verwys na die eiland Malta in die Middellandse See wat skuilplek aan Feniciese seevaarders in tye van gevaar en storms gebied het (KADW 1980b:3; RRP/A:11; Van Niekerk 2002:223). Die doel was nie slegs om die naasbestaandes van siek, beseerde of gewonde soldate van huisvesting te voorsien nie, maar ook om aan hulle die nodige geestelik bystand te verleen (KADW 1980a:3; RRP/A:11; RRP/B:23). Op hierdie wyse het kapelaansvroue nie alleen in 'n behoefte by die militêre gemeenskap voorsien nie, maar hulle pastorale versorging ook uitgebrei om die burgerlike gemeenskap in te sluit en die trauma van diegene wie se geliefdes in militêre operasies gewond of beseer is, te verlig. Met die opening van die oord het me Margot Malan, eggenote van die destydse Hoof van die SAW, daarop gewys dat diegene wat hulle geliefdes by 1 Militêre Hospitaal kom besoek het dikwels geskok en getraumatiseer was, en dikwels onbekend was met die omgewingsroetes en die verblyfmoontlikhede in Pretoria. Daarom beskryf sy Melita as: '[...] a deed of mercy' (KADW 1980b:1).

Melita is amptelik op 27 Augustus 1980 deur me Malan in gebuik geneem (KADW 1980b:1; RRP/B:23). Fondse vir die projek is van die Suiderkruisfonds verkry, ${ }^{10}$ asook skenkings deur individue en besighede. Hoewel die koste van die projek etlike duisende rande beloop het, het die goedgesindheid van die weermag en die publiek daartoe gelei dat die Kapelaansvrouekomitee die sleutel aan die SAW se Geneeskundige Dienste kon oorhandig sonder enige skuld kon oorhandig (Die kapelaansvroue SAW 1982:128; KADW 1980b:3; RRP/A:11).

Die Kapelaansvrouekomitee het 'n voltydse bestuurder aangestel wat saam met 'n komitee na die funksionering, instandhouding en benodigdhede by Melita moes omsien.

10.Vir meer inligting oor die Suiderkruisfonds en die Grensoorlog, sien onder andere Van Heerden (2014). 
Me Stassen ${ }^{11}$ het as bestuurder gedurende 1980 waargeneem, waarna me A. Bredenkamp vanaf 1981 tot 1988 diens gedoen het. In November 1988 het me E. Smith by haar oorgeneem (KADW 1980b:3; RRP/A:12-13; RRP/C:2 Melitaverslag).

Vanaf 28 Augustus 1980 tot 30 Junie 1983 het ten minste 1524 volwassenes en 114 kinders in Melita oorgebly. Die aanvraag na akkommodasie het egter die beskikbare ruimte oorskrei en op 30 Junie 1983 is 'n mobiele huiseenheid aangeskaf wat die akkommodasiegeriewe van 14 tot 22 beddens verhoog het. ' $n$ Bussie wat deur die Memorable Order of Tin Hats (MOTHS) geskenk is, het inwoners gratis tussen Melita en 1 Militêre Hospitaal vervoer (KADW 1983a:6; RRP/A:14-16; Van Niekerk 2002:223-224).

Die verskillende gemeentes van Voortrekkerhoogte het saam met die Kapelaansvrouekomitee, maandbeurte geneem om koffie, tee, suiker, skoonmaakmiddels en blomme aan Melita te voorsien. Hierdie gemeentes het verskillende denominasies verteenwoordig en het die Nederduitse Gereformeerde Kerk (NG Kerk), die Volle Evangelie Kerk, die Anglikaanse Kerk, die Gereformeerde Kerk, die Nederduitse Hervormde Kerk, die Rooms-Katolieke Kerk, die Apostoliese Geloofsending (AGS) en die Vrye Kerke ('n samevoeging van die Congregational Church, Presbiteriaanse Kerk, Baptiste Kerk en die Metodiste Kerk) ingesluit. Kapelane in die Pretoriaomgewing het saans tydens aandgodsdiensgeleenthede by die verblyfoord vir die inwoners gebid (Die kapelaansvroue SAW 1982:128; KADW 1988:8; RRP/A:11-12; Van Niekerk 2002:223-224).

Buiten die inwydingsfunksie op 27 Augustus 1980, het die Kapelaansvrouekomitee verskeie ander funksies met Melita as middelpunt gereël. Op 3 September 1980 is 'n bekendstellingsfunksie vir die Weermagdamesvereniging gehou. Ten einde die publiek aan die projek bekend te stel en om finansiële ondersteuning vir die projek te verkry, het die Kapelaansvrouekomitee op 27 Mei 1982 'n oggendtee te Voortrekkerhoogte gereël waar die eggenotes van die SAW se offisierskorps en sleutelfigure in vroueorganisasies, klubs, universiteite, kolleges en ander openbare belange oor die aard en behoeftes van Melita ingelig is. Op 24 Augustus 1990 is Melita se tiende verjaarsdag gevier. Talle vroue-organisasies het Melita ook by geleentheid besoek om eerstehands met die kapelaansvroue se pastorale uitreikaksie kennis te maak (KADW 1982d:8; 1986b:10; RRP/A:16-17; RRP/C:Afd. B; $\mathrm{RRP} / \mathrm{F})$.

Uit die talle dankbetuigingsbriewe blyk dit duidelik dat Melita in ' $n$ wesenlike behoefte voorsien het en gehelp het om die trauma rondom oorlogsbeserings te verlig, veral vir diegene wat van ver gekom het en Pretoria nie geken het nie. Sommige van die briewe sluit frases in soos: 'We enjoyed the relaxed, homely atmosphere', 'Melita is 'n Godgegewe oase' en 'Ons besef nou wat God met naasteliefde bedoel het' (KADW 1982c:8; Paratus 1982c:93; RRP/A:16; RRP/C:2 Melitaverslag).

11.Me Stassen se voorletters kon nie in die geraadpleegde bronne opgespoor word nie.

\section{Koffiekamers}

Kort nadat die SAP die verantwoordelikheid vir SWAPO insurgensie-aanvalle in 1973 aan die SAW oorgedra het, het kapelane wat die operasionele gebied besoek het, terugvoer gegee oor die gebrek aan behoorlike ontspanningsfasiliteite vir diegene wat grensdiens verrig het. Dit het tot die konsep van koffiekamers aanleiding gegee, en dit het ook as alternatief vir die kantien gedien (RRP/A:20; RRP/B:10, 22).

Genl.-maj. (ds.) C.P. Naudé is in 1976 as gebiedskapelaan van die operasionele gebied in die noorde van SWA aangestel en sy eggenote, Ria Naudé, het tydens hierdie tydperk eerstehands met die eise van grensdiens kennis gemaak. Grensdiens het haar van die kosbaarheid, maar ook die kwesbaarheid van die gesin bewus gemaak. Sy het besef hoe belangrik 'n stukkie 'normaliteit', soos tee en gebak, vir die grenssoldaat was (De Vos 1990:43; Van Rensburg 2012). Met haar man se diensaanvaarding as kapelaan-generaal in 1983, het sy die dryfkrag agter 'n uiters suksesvolle koffiekamerprojek geword; tot so 'n mate dat'n Amerikaanse Viëtnam-veteraan by geleentheid opgemerk het:

[...] if only we had something like that in Viëtnam [sic], if only our folks at home were so concerned about us, it could have changed the outcome of the war [...]. (De Vos 1990:43; vgl. ook $\mathrm{RRP} / \mathrm{E})$

Die doel van die koffiekamers was om ruimtes te skep waar die troepe in 'n huislike atmosfeer kon ontspan, na musiek luister, speletjies speel, lees, briewe skryf en Bybelstudie doen. Dit is dus van gepaste meubelment, matte, gordyne, geestelike lektuur, skryftafels, snoekertafels, vingerborde, 'n musieksentrum en 'n koffiemasjien voorsien. In 1981 is vier soortgelyke fasiliteite binne die operasionele gebied geskep en teen 1985 was daar reeds 48 koffiekamers in bedryf (Die Volksblad 1979:7; In Hoc Signo 1982:11; KADW 1985b:6; Paratus 1981:45). Die koffiekamers het gou in 'n sentrale bedieningspunt vir kapelane ontwikkel, en hoewel die sosiale verkeer gewoonlik informeel was, is daar op Woensdag- en Sondagaande Bybelstudiegeleenthede in die koffiekamers aangebied. Sommige koffiekamers soos die een by 52 SAI Bataljon te Ondangwa, het ook 'n aparte vertrek gehad waar die kapelaan persoonlike gesprekke kon voer. Die koffiekamerkonsep is ook na al die weermagbasisse in die Republiek uitgebrei (In Hoc Signo 1981:11; 1984a:11; KADW 1987:8; RRP/B:28).

Omdat kapelane weens hulle werklas nie self die projek kon bedryf nie en dit hoofsaaklik kerklike vroue-organisasies was wat die meubelment, toerusting en eetgoed aan die koffiekamers voorsien het, het die Kapelaansvrouekomitee verantwoordelikheid vir die skakeling en koördinering van die projek aanvaar. Lede van die Kapelaansvrouekomitee het die operasionele gebied gedurende 1984 besoek om 'n behoeftebepaling te doen. Op 3 Augustus dieselfde jaar het die Kapelaansvrouekomitee saam met lede van die Kapelaanshoofkwartier en ander belanghebbendes vergader om 'n werkswyse vir die projek vas te stel (RRP/A:20). Onder leiding van me Ria Naudé is reeds 
in 1983 besluit om die verskillende denominasies wat staandemagverteenwoordiging in die SAW het, te nader ten einde groter betrokkenheid van hulle vroueorganisasies by die koffiekamerprojek te verkry. 'n Beroep op wyer kerklike betrokkenheid het daaroe gelei dat vroue-organisasies van verskillende Afrikaanse denominasies, waaronder die NG Kerk, die Nederduitse Hervormde Kerk, die Gereformeerde Kerk, die AGS, die Pinksterkerke en die Sewendedag Adventiste, verantwoordelikheid vir spesifieke koffiekamers aanvaar het en dit met meubels en huislike geriewe toegerus het. Hierdie gemeentes het ook vier keer per jaar gebak gelewer en fondse vir die instandhouding van die koffiekamers voorsien. Behalwe die Kerspakkies en die briefies en kaartjies wat onder andere deur skoolkinders aan die soldate gerig is, is beskuit en koekies in groot volumes na die koffiekamers gestuur. Daar is bereken dat ongeveer $5000 \mathrm{~kg}$ gebak jaarliks tot en met die SAW-onttrekking op 01 November 1989 aan die operasionele gebied gelewer is. Die Engelse denominasies het nie by die projek ingeskakel nie ${ }^{12}$ (De Vos 1990:43; KADW 1985b:6; RRP/A:20-21; RRP/B:28).

Groepe dames het reeds sedert die laat-sewentigerjare van die vorige eeu die operasionele gebied as deel van 'n paraatheidsideaal besoek. Die eerste groep het uit Lugmagdames bestaan (RRP/B:13). Kapelaansvroue het vanaf 19 tot 21 September 1979 onder leiding van me. Elsa van Zyl hulle eerste besoek aan die operasionele gebied gebring en Windhoek, Rundu en Omega besoek (RRP/B:21; RRP/E:4). Na haar aanvaarding as Kapelaangeneraalsvrou en voorsitter van die Kapelaansvrouekomitee, het me Ria Naudé hierdie besoeke na die kerklike vroueorganisasies wat by die koffiekamerprojek betrokke was, uitgebrei. Die doel was nie alleen om hulle van die algemene toestande in die operasionele gebied bewus te maak nie, maar veral ook om hulle eerstehands aan die besondere behoeftes rondom die koffiekamerprojek bloot te stel (KADW 1985b:6; 1987:8; RRP/A:3, 21; RRP/B:28). In 1985 het 36 vroue van verskillende denominasies die operasionele gebied besoek en soortgelyke toere is tot 1988 onderneem. Veertig dames het die toer in April 1986 meegemaak en 37 dames die daaropvolgende jaar se toer. Op hierdie wyse is ook waardevolle interkerklike skakeling bewerkstellig (KADW 1985b:6; 1986c:10-11; 1987:8).

Met die beëindiging van die Grensoorlog in 1989 is die toerusting en meubelment van die operasionele koffiekamers wat nie by die Suid-Afrikaanse binnelandse koffiekamers of die Walvisbaaise koffiekamers gebruik kon word nie, verkoop en die fondse is in trust geplaas vir toekomstige gebruik deur binnelandse koffiekamers wat bly voortbestaan het. Gemeentes wat betrokke wou bly, is by die binnelandse koffiekamers heringedeel en daar is voortgegaan om gebak aan die eenhede in die binneland en by Walvisbaai te lewer (De Vos 1990:43; RRP/A:21; RRP/ D:Afd. C).

Talle berigte rondom die koffiekamerprojek en aanhalings van dankbetuigings deur soldate in In Hoc Signo getuig van ingeskakel het nie, sien Bredenkamp en Wessels (2010:50-53; 2011:8-10). die sukses van hierdie bediening. Vir baie was dit 'n stukkie 'huis' en 'n 'geestelike verrykingsplek', "n diensplek met ewigheidswaarde' (vgl. In Hoc Signo 1984a:11; 1984b:7; Van Rensburg 2012).

\section{Slotgedagtes}

Regdeur die geskiedenis van die mensdom het oorlogsomstandighede en konfliksituasies gemeenskappe aan trauma en 'n behoefte aan pastorale versorging blootgestel. Tradisioneel is hierdie versorging deur die religieuse samelewingsverband in 'n gemeenskap hanteer en het kapelane, as verteenwoordigers van die kerk, die soldate na die oorlogsfront vergesel. Navorsing het egter aangetoon dat vroue dikwels meer sensitief vir die behoeftes in 'n gemeenskap as hulle manlike eweknieë is. Kapelaansvroue is predikantsvroue in die volste sin van die woord, en as sodanig het hulle 'n geloofsboodskap om uit te dra. Daarom het Suid-Afrikaanse kapelaansvroue tydens die Grensoorlog van die standpunt uitgegaan dat hulle 'n eiesoortige bydrae kon lewer om die trauma van die destydse oorlogsomstandighede pastoraal te verlig.

Onder leiding van die Kapelaansvrouekomitee en deur die netwerke wat hulle georganiseer het, het hulle doelmatig in die behoeftes van die militêre gemeenskap voorsien. Op geestelike en fisiese vlak het hulle ondersteuning gebied en hulle uitreike het ook na die breër Suid-Afrikaanse gemeenskap uitgekring. Ouers kon in die koffiekamers geestelike bedieningsruimtes vir hulle seuns vind, en Melita het die trauma van oorlogsbeserings help verlig. Kapelaansvroue se diensbaarheid het tot ' $n$ verruiming van die kapelaansbediening van die SAKD bygedra en 'n onskatbare waardevolle diens aan die militêre gemeenskap van Suid-Afrika gelewer.

Erkenning van die pastorale uitreike van kapelaansvroue tydens die Grensoorlog verbreed die eendimensionele manlike interpretasie van die oorlog en werp lig op die algemene ondersteuningsrol van vroue in oorlogsomstandighede. Dit toon aan dat gelowige vroue deur hulle vindingrykheid en die vermoë om situasies te hanteer, daartoe kan bydra om die kontoere van'n gemeenskap onder abnormale omstandighede en trauma bymekaar te hou. Navorsing het aangetoon dat vroue dikwels tydens oorlog- en konflikomstandighede 'n uitsonderlike sterkte kan toon en soos die kapelaansvroue, as bakens van hoop en heropbou in 'n gemeenskap na vore kan tree. Daarmee word die grense van kulturele en sosiale tradisies met betrekking tot vrouwees verskuif en word die waarde van gelowige vroue in maatskaplike samelewings bevestig.

Werke deur gender-historici verwys dikwels na die afwesigheid van vroue in die hoofstroomgeskiedskrywing en die leemtes wat daardeur veroorsaak word (vgl. Scott 1996:2-5). Omdat uiteindelik slegs die geskiedenis wat verwoord is van belang is en saak maak (Ntwape 2016:1), volg dit uiteraard dat die geskiedenis van die SAKD se 
betrokkenheid by die Grensoorlog altyd onvolledig sal wees indien die pastorale teenweer van kapelaansvroue teen oorlogstrauma nie ook in aanmerking geneem word nie.

\section{Erkenning \\ Medeingende belange}

Die outeurs verklaar dat hulle geen finansiële of persoonlike verbintenis het met enige party wat hulle nadelig kon beïnvloed het in die skryf van hierdie artikel nie.

\section{Outeurs bydrae}

As eerste outeur het I.B. die basiese navorsing en skryf van hierdie artikel gedoen, met A.W. wat as tweede outeur ' $n$ sekondêre rol gespeel het.

\section{Literatuurverwysings}

Barnard, L., 2002, 'Life on the border: A socio/historic study of the members of the South African Air Force during the "Bush War," 1966-1989', Joernaal vir Eietydse Geskiedenis 27(1), 35-47.

Blignaut, C., 2012, Volksmoeders in die kollig: 'n Histories-teoretiese verkenning van die rol van vroue in die Ossewa-Brandwag, 1938 tot 1954, Meestersgraadverhandeling, Noordwes-Universiteit, Potchefstroom, viewed 9 September 2016, from https://dspace.nwu.ac.za/bitstream/handle/10394/8108/Blignaut_ C.pdf

Bonnin, D., 1996, 'Women's studies in South Africa', Women's Studies Quarterly 24(1/2), 378-399.

Boshoff, C., 1982, 'Wêreld vol slaggate vir grens-"weduwees"', Die Vaderland, 26 April, bl. 13. Botha, A., 1978, "n Lappop vir 'n soldaat by die grens', Die Transvaler, 11 Mei, bl. 13.

Bredenkamp, I. \& Wessels, A., 2010, 'Die Suid-Afrikaanse Kapelaansdiens en die beginsel van 'n regverdige oorlog: die Namibiese Vryheidsoorlog, 1966-1989', Joernaal vir Eietydse Geskiedenis 35(1), 39-61.

Bredenkamp, I. \& Wessels, A., 2011, 'Die Suid-Afrikaanse Kapelaansdiens (SAKD) en staatsbeleid tydens die Grensoorlog, 1966-1989', Acta Theologica 31(1), 1-19. http://dx.doi.org/10.4314/actat.v31i1.1

Bredenkamp, I. \& Wessels, A., 2012, 'A historical perspective on military chaplaincy services in the South African National Defence Force (SANDF), 1998-2002' Joernaal vir Eietydse Geskiedenis 37(2), 242-267.

Bredenkamp, I. \& Wessels, A., 2014a, "n Historiese perspektief op die kapelaansvrou in die Suid-Afrikaanse militêre milieu', New Contree. A Journal of Historical and Human Sciences for Southern Africa 69, 120-140.

Bredenkamp, I. \& Wessels, A., 2014b, 'The early history of South African military chaplaincy: A case study of the variance between British imperialism and Afrikaner nationalism, c.1914-1973', Joernaal vir Eietydse Geskiedenis 39(2), 60-80.

Bredenkamp,I.\&Wessels,A., 2015,"nHistorieseperspektiefopdieKapelaansvrouekomitee, c.1970-1990', Joernaal vir Eietydse Geskiedenis 40(1), 77-101.

Cock, J., 1991, Colonels \& cadres. War and gender in South Africa, Oxford University Press, Oxford.

Cock, J. \& Nathan, L. (reds.), 1989, War and society. The militarisation of South Africa David Philip, Kaapstad.

Cohn, C. (red.), 2013, Women \& wars, Polity Press, Cambridge.

Cornelissen, L., 2013, 'Kapelaangeneraalsvrou 2004-2011', Onderhoud met I. Bredenkamp, navorser by Universiteit van die Vrystaat, Bloemfontein.

Dale, R., 2014, The Namibian War of Independence, 1966-1989. Diplomatic, economic and military campaigns, McFarland \& Company, Inc., Publishers, Jefferson City, MO.

De Vos, W., 1990, 'Portret van 'n vrou. Ria Naude: 'n vrou tot beskikking van die Here', Die Voorligter, Mei, bl. 41-43.

Die Kapelaansvroue SAW, 1982, Die Kapelaansvrou, Daan Retief Uitgewers, Pretoria.

Die Transvaler, 1993, 'Vroue sal saam met mans veg', Die Transvaler, 1 Maart, bl. 12.

Du Toit, H.D.A., 1955, Olie op die wonde. Die diakonaat in teorie en praktyk, N.G. Kerkuitgewers, Kaapstad. Kerk en Volk-reeks no. 11.

Hendriks, J., 1999, Gemeente als herberg. De kerk van 2000: een concrete utopie, Uitgeverij Kok Kampen, Kampen.

Heyns, J., 1977, Die kerk, Nasionale Boekdrukkery, Elsiesrivier.

In Hoc Signo, 1981, 'Christelike koffiekamer te P.D.', Skool. 6(2) Julie, bl. 10-12.

In Hoc Signo, 1982, 'Ondangwa kry koffiekamer', 7(1) Maart, bl. 11.

In Hoc Signo, 1984a, '2 Koffiekamers in Sektor 70', 10(1) Mei, bl. 11.

In Hoc Signo, 1984b, Koffiekamers op grens beteken baie, 10(2) Oktober, bl. 7.
Joernaal vir Eietydse Geskiedenis, 2006, 31(3), Spesiale uitgawe, Grensoorlog 19661989, Desember, passim

Joernaal vir Eietydse Geskiedenis, 2009, 34(1), Spesiale uitgawe (Deel 2), Grensoorlog 1966-1989, Februarie, passim.

Kapelaansvroue aan die woord (KADW), 1980a, 'Kapelaansvroue skep noodhuisvesting', In Hoc Signo 5(2) Junie, bl. 3.

Kapelaansvroue aan die woord (KADW), 1980b, 'Melita - A deed of mercy', In Hoc Signo 5(3) November, bl. 1, 3

Kapelaansvroue aan die woord (KADW), 1981, 'Kersfeesaksie 1980', In Hoc Signo 6(1) Maart, bl. 4-5.

Kapelaansvroue aan die woord (KADW), 1982a, 'Nuus-brokkies', In Hoc Signo 7(1) Maart, bl. 6.

Kapelaansvroue aan die woord (KADW), 1982b, 'Kersfeesaksie 1981', In Hoc Signo 7(1) Maart, bl. 7-8.

Kapelaansvroue aan die woord (KADW), 1982c, 'Briewe', In Hoc Signo 7(1) Maart, bl. 8.

Kapelaansvroue aan die woord (KADW), 1982d, 'Melita tea', In Hoc Signo 7(2) Julie, bl. 8.

Kapelaansvroue aan die woord (KADW), 1983a, 'Mobile unit for Melita', In Hoc Signo 9(2) September, bl. 6.

Kapelaansvroue aan die woord (KADW), 1983b, 'Kersfeesaksie 83', In Hoc Signo 9(3) Desember, bl. 6-7.

Kapelaansvroue aan die woord (KADW), 1985a, 'Kersfeesaksie', In Hoc Signo 11(1) Februarie, bl. 6 .

Kapelaansvroue aan die woord (KADW), 1985b, 'Dames besoek opsgebied', In Hoc Signo 11(2) Mei, bl. 6.

Kapelaansvroue aan die woord (KADW), 1986a, 'Kersaksie 'n sukses', In Hoc Signo 12(2) Junie, bl. 7.

Kapelaansvroue aan die woord (KADW), 1986b, 'Women's group from Warmbaths visits Melita', In Hoc Signo 12(3) November, p. 10.

Kapelaansvroue aan die woord (KADW), 1986c, 'Vroue met flossie grens toe', In Hoc Signo 12(3) November, bl. 10-11.

Kapelaansvroue aan die woord (KADW), 1987, 'Vroue besoek opsgebied', In Hoc Signo 13(2) September, bl. 8.

Kapelaansvroue aan die woord (KADW), 1988, 'Miss Bredenkamp's farewell from Melita', In Hoc Signo 14(2) November, pbl. 7-8.

Klingorová, K. \& Havlíč, T., 2015, 'Religion and gender inequality: The status of women in the societies of world religions', Moravian Geographical Reports 23(2), 2-11.

Kumar, K. (red.), 2001, Women \& civil war. Impact, organizations, and action, Lynne Rienner Publishers, Boulder, CO.

Lindsey, C. 2001. Women facing war. Geneva: International Committee of the Red Cross (ICRC).

Marwick, A., 1977, Women at war 1914-1918, Croom Helm, London.

Meiring, I., 2012, Dienspligkapelaansvrou, Onderhoud met I. Bredenkamp, Bloemfontein, navorser by Universiteit van die Vrystaat, 18 Junie.

Ntwape, L.F., 2016, A historiography of South African women's history from c. 1990 A survey of monographs, anthologies and journal articles, Meestersgraadverhandeling, Universiteit Pretoria, Pretoria, viewed 6 September 2016, from http://repository.up.ac.za/dspace/bitstream/handle/2263/51414/Ntwape Historiography_2016.pdf

Organisation for Appropriate Social Services in South Africa (OASSSA), 1988 'Conspiracy of silence: Women and democracy', Die Suid-Afrikaan, 17 OktoberNovember, p. 13.

Paratus, 1981, 'Rundu-koffiekroeg goed op dreef', Paratus, Augustus, bl. 45.

Paratus, 1982a, 'Kapelaansvroue gee geskenke', Paratus, Maart, bl. 75.

Paratus, 1982b, 'Soldate moet verstaan word om gehelp te kan word', Paratus, Junie, bl. 111.

Paratus, 1982c, 'Kapelaansvroue stel hul Melita met 'n dankbare hart bekend', Paratus, Julie, bl. 93.

Peterson, V.S., 2008, “'New wars” and gendered economies', Feminist Review 88, 7-20.

Potgieter, J.F., 1971, Die militêre kapelaan: die ontstaan en ontwikkeling van die amp, taak en organisasie van militêre kapelane in die geskiedenis van die Christelike kerk, met besondere verwysing na Suid-Afrika, Ongepubliseerde doktorale proefskrif, Universiteit van Pretoria, Pretoria.

Ria van Rensburg Privaatversameling (RRP):

RRP/A: Die Kapelaansvroue: Geskiedkundige oorsig.

RRP/B: Geskiedenis van die Weermagdamesvereniging/History of the Defence Force Ladies Association.

RRP/C: Verslag kapelaansvroue, 1989.

RRP/D: 'n Oorsig oor die aktiwiteite van die Kapelaansvrouekomitee vanaf $1 \mathrm{Me}$ 1983-30 November 1990.

RRP/E: Brief van Ria Naudé aan kapelaansvroue, Maart 1988.

RRP/F: Brief van Ria Naudé aan kapelaansvroue, 10 Februarie 1990.

RRP/G: Die vrou op die tuisfront. 
Samuel, K., 2001 'Gender difference in conflict resolution: The case of Sri Lanka', in I. Skjelsbæk \& D. Smith (reds.), Gender, peace \& conflict, pp. 184-204, Sage, London. Scholtz, L., 2013, Die SAW in die Grensoorlog 1966-1989, Tafelberg, Kaapstad.

Scott, J.W. (red.), 1996, Feminism \& history, Oxford University Press, Oxford.

Skjelsbæk, I., 2001, 'Is femininity inherently peaceful? The construction of femininity in war', in I. Skjelsbæk \& D. Smith (reds.), Gender, peace \& conflict, pp. 47-67, Sage, London.

Skjelsbæk, I. \& Smith, D. (reds.), 2001, 'Introduction', in I. Skjelsbæk \& D. Smith (reds.), Gender, peace \& conflict, pp. 1-13, Sage, London.

Spies, F.J. du T., 1989, Operasie Savannah: Angola 1975-1976, SA Weermag, Direktoraat Openbare Betrekkinge, Pretoria.

Steenkamp, W., 1989, South Africa's Border War, 1966-1989, Ashanti Publishers, Gibraltar.

Steyn, D. \& Söderlund, A., 2014, Iron fist from the sea. South Africa's seaborne raider 1978-1988, Helion \& Company Limited, Solihull.

Strauss, A., 2006, 'Die betrokkenheid van vroue in ' $n$ era van oorlog', Joernaal vir Eietydse Geskiedenis 31(3), 370-398.

The Friend, 1979, 'Everyone involved in defence effort', The Friend, 1 Junie, p. 4.
Treacher, A., Pai, H., Khalili, L. \& Alldred, P., 2008, 'The gendered embroilments of war', Feminist Review 88, 1-7. http://dx.doi.org/10.1057/palgrave.fr.9400404

Van Heerden, A., 2014, Die Suiderkruisfonds en die mobilisering van die SuidAfrikaanse blanke burgerlike samelewing tydens die Grensoorlog, 1968-1989, Meestersgraad-verhandeling, Universiteit Stellenbosch, Stellenbosch, viewed 9 November 2015, from http:www.scholar.sun.ac.za

Van Niekerk, S.G., 2002, The history, role and influence of the South African military chaplaincy: 1914-2002, Ongepubliseerde doktorale proefskrif, Universiteit van Suid-Afrika, Pretoria.

Van Rensburg, R., 2012, Kapelaangeneraalsvrou 1983-1990, Onderhoude met I, Pretoria Bredenkamp, navorser by Universiteit van die Vrystaat, 5 Augustus en 22 Oktober.

Van Tonder, J.M., 2014, Die pastorale rol van die Hollands-Afrikaanse kerke gedurende die Tweede Wêreldoorlog (1939-1945): 'n kerkhistoriese studie, Ongepubliseerde doktorale proefskrif, Noordwes Universiteit, Potchefstroom.

Wessels, A. \& Bredenkamp, I., 2009a, 'Military chaplaincy in the South African Defence Force during the Namibian War of Independence', Joernaal vir Eietydse Geskiedenis 34(13), 318-338.

Wessels, A. \& Bredenkamp, I., 2009b, 'Suid-Afrikaanse kapelane in 'n era van militêre konflik, 1966-1989: Enkele persoonlike ervarings en perspektiewe', Joernaal vir Eietydse Geskiedenis 34(13), 339-360. 